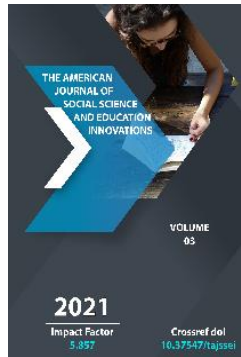

\title{
Specific Aspects Of The Formation Of An Individual's Ability To Innovate In The Process Of Education
}

\author{
Abdurahmonov Hasan Ibrohimovich, \\ Independent Researcher Of Tashkent State Transport University, Uzbekistan
}

Journal Website:

http://usajournalshub.c

om/index,php/tajssei

Copyright: Original content from this work may be used under the terms of the creative commons attributes 4.0 licence.

\section{ABSTRACT}

It consists in the theoretical and methodological determination of the future prospects of meeting the needs of highly qualified innovation-thinking specialists necessary for the life of society by opening up the general laws of the integration of the knowledge accumulated by our great ancestors and their followers in the field of natural, social and humanitarian sciences into the minds of educators.

\section{KEYWORDS}

Individual ability, education, innovation, pedagogical skills, methodology, quality of education.

\section{INTRODUCTION}

The formation of a person with innovative thinking is a modern requirement. Because, an innovative person is a talented person, capable of creating scientific and practical works, introducing new ideas aimed at developing, changing the material and spiritual life of society, as a result of the clever understanding of nature, society, what is happening in human 
thinking, the mysteries of events and processes and scientific knowledge. Of philosophical importance in bringing it to adulthood, first of all, the formation and development of an innovative personality, socio-philosophical, which monandically determines the meaning, main direction of the period; secondly, the scientific and practical principles used in the organizational and methodological maintenance of the formation and development of an innovative personality are used.

The formation and development of an innovative personality is brought into action on the basis of innovative infrastructures. It is carried out mainly in two large areas: the creation and commissioning of the innovation infrastructure of the formation of an innovative personality within the framework of the educational system; outside the framework of the educational system, that is, in the creation and commissioning of the innovation infrastructure of the formation of an innovative personality by the centers of scientific and production.

There are tendencies inherent in the formation and development of an innovative personality, which indicate that there are different directions of bringing up an innovative person in every possible way and bringing up an adult. In the formation of an innovative personality, the professional competence of the educator and the merit of the educator play an important role. A subject with low professional competence and a person without scientific merit can impede the social development of society due to the inability to create innovative ideas and scientific and practical works.
The formation of an innovative personality is brought into action on the basis of innovative infrastructures. Therefore, it is important to use reproductive techniques aimed at the creation, commissioning and development of innovative infrastructure aimed at the development and improvement of an individual's innovative abilities.

\section{MATERIALS AND METHODS}

President Sh.M.Mirziyoev's: "innovation means the future. If we are going to start the restoration of our great future from the Steam, then we should start it on the basis of innovative ideas, an innovative approach," his thoughts indicate that the country is a philosophical methodological - conceptual basis for development .

Innovative activity is described as a system of processes aimed at reforming, modernizing, developing certain spheres of society, creating new ideas, scientific and practical works, introducing them into practice by a responsible person, scientific community, educational institutions, research institutes, production associations, constructorship-experimental offices, etc.

Any innovation activity is bilateral, firstly, the application of the results of innovative activities in the educational process; on the second hand, it has such a feature as carrying out innovative activities through the educational process, the first of which serves as a concerted basis for the formation, development and transformation of the educational process, and the second is a process that forms the The basis of its implementation is innovation education. 
Innovative person - this is what is happening in nature, society, human thinking, as a result of the ingenuity of understanding and scientific knowledge of the mysteries of events and processes, promoting new ideas aimed at the development, transformation of the material and spiritual life of society, creating scientific and practical works, introducing them into practice, describing them as a talented person, forming and developing ittirishga, science, which determines its main direction; orientation towards the acquisition of professions of practical significance based on fundamental knowledge; systematization, consistency andeksexuality; sociophilosophical, which consists of a team, group and individual approach, etc.; secondly, it is possible to divide innovation into scientific and practical principles used in the organizational and methodological maintenance of the formation and development of the individual.

By forming an innovative person on the basis of information, we enter into the sentence the developing methods: a) lectures, storytelling, narration, conversation, videofilms, which are considered ready information; b) information that is sought independently, that is, information collected on the basis of independent work on books, independent mastering of science programs and other similar independent types of work. In this, the methods used are: evristik conversation; performing search work in the laboratory; arguing in teaching and learning; acting as research in reading.

To the second group-aimed at strengthening knowledge, the formation of abilities and skills, aimed at the cultivation and improvement of the innovative abilities of the individual-we introduce reproductive and creative reproducing methods. To the methods of reproduction in this: recursive storytelling of the training material; repeating exactly the exercises indicated by the andose; performing laboratory work on the basis of the instruction; working in simulators; creative-repeatedly (repeatedly) producing methods: creatively discussing the questions that are expected to be covered in the chosen topic; solving alternative exercises; we analyze the situation in the production; solve the situational tasks that arise in the production; organize games with different innovative content, and so on. Therefore, "no matter what activity a person is engaged in, all of them can be drawn to the game front. Through the game, a person realizes himself and reality, assimilates, imitates natural, personality and social phenomena, he or she plays a role. Innovation thinking is also a kind of intellektual activity that can be drawn to the game front. In innovative thinking, the manifestation of the game finds its expression in various shapes and models."

In the sentence of means aimed at the cultivation and improvement of the innovative abilities of a person in the process of Education: evidence, visual numbers, numbers, documents, information and normative-legal acts, letters, scientific-spiritual images of innovators, drawings, tables, videographs, photographs, albums, layouts, simulators, technical means, samples of Information Technology and other technical and labor weapons, excerpts from films, artistic and scientific literature, textbooks, blackboard, we enter the text of the lecture, and so on.

Innovation is the innovation infrastructure of formation and development of a person, a philosophical definition is given that promotes 
new ideas aimed at developing, changing the material and spiritual life of society, creates scientific and practical works, introduces them into practice, is a talented person-various auxiliary organizational-social institutions, organizations that serve people in an innovative way in the development of adulthood. Its implementation is mainly in two major areas: first, the education system-in the framework of preschool, primary and general secondary, academic lyceums and vocational colleges, higher education;

Secondly, it is desirable to carry out by the Centers of innovation, ideas, developments and technologies outside the scope of the educational system, namely scientificproduction facilities, experimental-testing areas, by-laws of invention and rationalization, in other words, the creation and commissioning of the innovation infrastructure for the formation of an innovative personality.

Measures for the creation and commissioning of infrastructure for the formation and development of an innovative personality, the main driving force of innovative development of the country, are defined in a number of decrees and resolutions of the president of the Republic of Uzbekistan .In it, the main focus is on the creation of "centers of innovative ideas, developments and technologies".

It was determined that there are a number of complex measures on the basis of scientifically harmonization of the innovative educational model; carrying out innovative activities in the educational process, depending on the differentiation and integration of Sciences; filling the labor market with competitive specialists with innovative thinking; on the basis of continuous development of science, there are trends aimed at solving the issues

In the formation and development of an innovative personality, on the one hand, the determination of the degree of competence and competence characteristics of an educational subject is an important scientific and practical issue. Competency is the ability of an individual to perform a job in one area and, accordingly, the scope of powers granted to him, formally or informally, while merit is the ability of any individual to perform a job in another. Competency plays a decisive role in competency. This is manifested in different forms and levels, depending on the time, size, content of the work-activity performed by the person and society.

The high stage of formation and development of an innovative personality is higher educational institutions, in which the subject of an innovative personality as a specialist is an adult-this is the corps of professors and teachers. Innovation person is said to be professional competence of adult learners to demonstrate their abilities in innovative teaching, professional orientation innovation work activities within the framework of the competencies given to each teacher depending on the levels of his / her specialty. Their competence is structured from the components of activity, predictability and subjectivity, each of which reveals those or those aspects of competence. The merit of an innovative educational subject: 1) Personalthis is at what level of the formation of his qualities, the decision - making of an active life and civil position; 2) creative (English "sreate" creativity, creativity) - the ability to create news, creativity, organization, etc.; 3) information - formation of skills of analysis, 
selection, processing and transfer of necessary information in connection with personal and professional activities in the means of modern information and communication technologies; 4) innovation-awareness of the essence of innovative processes in education, mastering innovations in the sphere of professional activity and related education, active application to practice, literacy in the field of modern pedagogical, information and innovation; 5) it is determined that there are such types of effective organization of methodical-educational and managerial processes as knowing, mastering, applying in practice the forms, methods and tools, studying international experiences of professional activity, designing the educational and educational process, carrying out them successfully . Educating a worthy innovative person in every way is one of the forces ensuring continuity of social development of our society.

\section{RESULT AND DISCUSSION}

In modern conditions, innovation is a new factor of development of society and personality, which allows us to think about the transition to a new model of society - an innovative society. At the same time, in the creation, distribution and implementation of innovations based on innovative thinking, people are also faced with contradictions between tradition and modernity. That is, the contradictions that have arisen today between traditionalism and modernity have become a broad-coverage phenomenon, which includes its wider use in modern society through the implementation of a model of innovative development. This complex situation arises under the influence of hyperdynamic innovation development or "innovation racing".

A distinctive feature of this problem in modern social philosophy is that, first of all, not one of the existing models of society can see the perspective aspects of its development without taking into account the radical changes that the society is experiencing under the influence of innovative processes. Secondly, the processes of creation, transmission, distribution and use of innovations that change the structural direction of the life of a person and society rely on specific dialectical laws. Because today, innovations created on the basis of Science, Science and technological progress are becoming a factor of the emergence of new forms of contradictions at different levels in society, their comprehensively encompassing nature is manifested through the uncertainty of the innovative development of society.

On this basis, we will not be mistaken if we say that the innovative development of society is the emergence of these historically unprecedented contradictions. At the same time, innovation changes, on the one hand, provide for the formation of new social and personal needs, but on the other hand, they often endanger the basic values - security, physical and mental health, originality, traditions, which represent a high level of danger of the innovative society. In the conditions of intensive scientific and technical development, scientific, technical, financial, educational, as well as many other innovations and unpredictable consequences of production based on them, create problems at different levels. At the same time, innovative development, which includes the formation and implementation of new ideas and 
approaches in all aspects of society, reflects dialectical legislation that goes into various forms and requires constant management.

Stability is tied to the content and implementation of innovations that differ in nature. The development of innovations, the creation of conditions for their implementation and the willingness of members of the society to master the countless innovations characterize the type of innovation in development, the bunda technocratic ideology finds its maximum expression. Despite the desire to get rid of the constraints through innovation, the type of development based on innovation also has different limits.

Innovation mentality forms the fundamental basis of the innovation process. Innovation processes in society can continue without great losses (in most cases this is due to the introduction of technical innovations) and extremely difficult (with the introduction of social innovations). On the one hand, innovative processes contribute to the stabilization of socio-economic and sociocultural situations, as they arise in response to the internal stress of the social system or its components. The introduction of innovations will lead to the solution of the problem of dependence and, as a result, to a stable balance of the system. On the other hand, uncontrolled news releases instability in the system and it is also possible that the social system divides it into unbalanced components. This phenomenon is associated with the manifestation of a new one in a radically aggressive form in the sense that denies the old one. At the same time, the innovative type of development is becoming the leading direction of the strategy of modern civilization. This strategy is based on the recognition of the complexity and instability of the social environment it is an expression from constant changes. In this regard, it is necessary to change the society and at the same time create suitable conditions for its development.

Scientific and innovative activity is the creation of scientific innovations that must be understood as scientific innovations and inventions. This concept represents a special field of science of man. Scientific and innovative activity ensures the unity of activity for the acquisition and application of new scientific knowledge. The unit of two different types of activity (cognitive and practical) is dialectically dependent, because the goals and tools of scientific knowledge do not always fully correspond to the practical needs and ways of achieving them. The unit of cognitive and practical activity in modern science is based on special and extremely important activities such as commercialization of scientific works in the innovative economy.

In the structure of scientific and innovative activity, it is possible to distinguish such main directions as fundamental and applied research, experimental research that forms a practical "scientific" part, as well as the design of scientific developments and inventions in the form of intellektual property and the creation of models for their commercialization. The composition of scientific and innovative activity in dynamics can be represented in the form of the following stages: basic scientific knowledge - invention - scientific innovation distribution. In our opinion, the issue of commercialization of scientific works should be considered not only in the direction of "science - production", but also in the direction of "science - scientific innovation". 
Scientific and innovative activity requires the acquisition of scientific and innovative activity in the direction of "scientific and scientific innovation", including research and classical relations and rights in modern economic conditions. The ownership of scientific work in this process is determined by these scientific achievements and the transfer of work to the market. The subject and purpose of this type of activity (additional communication) is the creation of models for the commercialization of scientific works (transformation of inventions into innovations). This type of activity is manifested in the form of a special type of entrepreneurial activity, which has all the consequences for its organization and management. For a holistic theoretical understanding of this type of activity, it is necessary to design it in the form of a new concrete science.

The methodology of scientific and innovative activity is as follows:

- Analysis of the role and location of components that determine the effectiveness of commercialization of scientific works;

- The analysis of whether the innovator corresponds to the value of scientific innovation is determined by trade secrets (uncertainty and complexity of technology) and additional production opportunities, trade and service, despite the various variations in the industry.

- Every business project in the science allows the scientific development market and the creation of a suitable commercialization model for it.
Models of commercialization of scientific works are an important element in the transformation of inventions into scientific innovations. Scientific and innovative activity is the activity of creating scientific innovations, which should be understood as scientific innovations and inventions. The innovation system is the subsystem of society, primarily the economy, its renewal, development, which is aimed not only at reproduction, reproduction of all levels achieved, but also at reproduction. The basis of the innovation system is scientific and innovative activity.

The innovation system is the subsystem of society, primarily the economy, its renewal, development, which is aimed not only at reproduction, reproduction of all levels achieved, but also at reproduction. The basis of the innovation system is scientific and innovative activity.

\section{CONCLUSION}

In summary, the nature of social innovations is manifested in a two-sided form. On the one hand, they bring constructive changes to social life, on the other hand, they involve the risk of social destruction. The destructive potential of social innovations is reflected in the form of their important properties, for example, high degree of uncertainty and danger, the presence of a large number of side changes, adverse effects and pathologies, conflicts. The possible negative consequences of the introduction of social innovations into the life of society can be the malfunction or disappearance of certain spheres of social life and their elements, a major innovation shock (physical and mental disorders, social deviations and destructive social escapism). The manifestation of social innovations in the 
system of social relations in a destructive form are innovative conflicts (physical violence, rallies, pickets, demonstrations, strikes, hunger strikes, social unrest, riots, violent revolutions, etc.), which, if not resolved in a timely manner, can lead to resistance to many discontent and innovations in society.

\section{REFERENCES}

1. Мирзиёев Ш.M. Ўзбекистон Республикаси Президенти Шавкат Мирзиёевнинг Олий Мажлисга Мурожаатномаси.- Т.: “Ўзбекистон” НМИУ, 2018.- Б. 19-20.

2. Рудаков П.Г. Социально-философские основания процесса формирования инновационной личности : диссертация ... кандидата философских наук :. Москва, 2012. - 170 с.

3. Кубаева Ш.Т. Ўйин ва инновацион тафаккур (онтологик ва гносеологик тахлил). Фалсафа фанлари бўйича фалсафа доктори (PhD) диссертацияси автореферати. - Самарқанд 2019. -Б.17.

4. Ўзбекистон Республикаси Президентининг "Ўзбекистон Республикасини янада ривожлантириш бўйича харакатлар стратегияси тўғрисида" (2017 йил 7 февралдаги ПФ4947-сонли), “Ўзбекистон Республикаси Инновацион ривожланиш вазирлигини ташкил этиш тўғрисида”(2017 йил 29 ноябрдаги ПФ-5264-сон),“Фаол тадбиркорлик ва инновацион фаолиятни ривожлантириш учун шартшароитларни яратиш бўйича қўшимча чора-тадбирлар тўғрисида"(2018 йил 5 май), “Иқтисодиёт тармоқлари ва сохаларига инновацияларни жорий этиш механизмларини такомиллаштириш бўйича қўшимча чора-тадбирлар тўғрисида" (2018 йил 7 май), "2019-2021 йилларда Ўзбекистон Республикасини инновацион ривожлантириш стратегиясини тасдиқлаш тўғрисида" (2018 йил 21 сентябрдаги ПФ-5544-сон) фармон ва қарорлари.

5. Ўзбекистон Республикаси Президентининг “Иқтисодиёт тармоқлари ва сохаларига инновацияларни жорий этиш механизмларини такомиллаштириш бўйича қўшимча чора-тадбирлар тўғрисида" Қарори. (2018 йил 7 май).

6. Коломиец О.М. Деятельностная основа профессиональных компетенций преподавателя высшей школы.// Вест. Моск.Ун-та.Сер.20. Педагогическое образование. -2015. -№ 2.- С.15.

7. Ишмухамедов Р.,Мирсолиева М. Ўқув жараёнида инновацион таълим технологияари. texnologiya", 2014.- Б. 8-9.

8. Рыкун А.А. Философская проблематизация применения новейших информационных технологий в научно инновационной деятельности личности: диссертация...кандидата философских наук. - Пятигорск, 2004. $177 \mathrm{C}$

9. Farxodjonova N. F., Abdurahimov V. A. MODERN TECHNOLOGIES OF STUDENTS TRAINING IN HIGHER EDUCATION //НАУКА И ТЕХНИКА. МИРОВЫЕ ИССЛЕДОВАНИЯ. - 2020. - С. 5-7.

10. Farxodjonova N. F. Modernization Of Uzbek Language And National-Spiritual Heritage In National Culture". The American Journal of Social Science and Education //Innovations. - 2021. - T. 3. - №. 01. - C. 585 . 
The American Journal of Social Science and Education Innovations (ISSN - 2689-100x)

Published: April 30, 2021 | Pages: 708-716

11. Farxodjonova N. F. Modernization and integration: social-philosophical analysis. Rol'nauki $v$ formirovanii sovremennoj virtual'noj real'nosti. - 2019.

12. Sodirjonov, M. M. (2020). EDUCATION AS THE MOST IMPORTANT FACTOR OF HUMAN CAPITAL DEVELOPMENT. Theoretical \& Applied Science, (4), 901905. 